\title{
PENINGKATAN HASIL BELAJAR IPS MELALUI MODEL KOOPERATIF TEKNIK MENCARI PASANGAN KARTU SOAL SISWA KELAS V SD

\author{
BADRIYAH
} \\ SD NEGERI 2 JATIMULYO \\ "E-mail: badriyah.2402@gmail.com
}

Abstrak

\begin{abstract}
Peningkatan Hasil Belajar IPS Melalui Model Kooperatif Teknik Mencari pasangan Kartu Soal Siswa Kelas V SD Negeri 2 Jatimulyo. Tujuan penelitian ini adalah untuk meningkatkan hasil belajar siswa pada mata pelajaran IPS dengan menggunakan model pembelajaran kooperatif teknik mencari pasangan kartu soal di kelas V SD Negeri 2 Jatimulyo. Jenis penelitian ini yaitu Penelitian Tindakan Kelas (PTK). Penelitian tindakan kelas ini terdiri dari empat tahap yaitu perencanaan, pelaksanaan, observasi, dan refleksi. Subjek penelitian ini adalah siswa kelas $V$ yang berjumlah 14 orang siswa. Analisis data menggunakan teknik tes, observasi, dan dokumentasi. Berdasarkan tahap pelaksanaan siklus, mengalami peningkatan terbukti nilai rata-rata pada siklus I mengalami peningkatan dibanding pra siklus yaitu dari 54,28 menjadi 67,85 , dengan presentase ketuntasan $28,5 \%$ menjadi $57,14 \%$. Kemudian rata-rata pada siklus II meningkat dari siklus I yaitu dari 67,85 menjadi 85,7 , dengan presentase ketuntasan $57,14 \%$ menjadi $85,7 \%$. Dapat disimpulkan dengan menggunakan Model Pembelajaran mencari pasangan kartu soal dapat meningkatkan hasil belajar siswa.
\end{abstract}

Kata kunci : Hasil Belajar, Pembelajaran IPS SD, model kooperatif teknik Mencari Pasangan Kartu Soal.

\section{PENDAHULUAN}

Mata pelajara IPS merupakan salah satu nama nama mata pelajaran yang diberikan pada jenjang pendidikan dasar dan menengah (Sapriya, 2009:7). Pentingnya belajar IPS tidak telepas dari banyaknya permasalahan dalam kehidupan masyarakat yang semakin berkembang, pembelajaran IPS akan membimbing siswa menghadapi kenyataan dalam lingkungan sosialnya dan dapat menghadapi masalah-masalah social yang terjadi dengan lebih arif dan bijaksana. Berdasarkan hasil observasi dan wawancara peneliti di SD Negeri 2 Jatimuyo, ketika peneliti mengamati proses belajar mengajar IPS di kelas $V$ diketahui selama proses pembelajaran IPS berlangsung keaktifan siswa dalam pembelajaran masih sangat rendah begitu pula dengan interaksi antara siswa dengan siswa serta siswa dengan guru, hal tersebut terjadi karena pembelajaran sebagian besar masih dilakukan dengan format penyampaian informasi, yang mengunakan metode ceramah dan tanya jawab sehingga membuat kreatifitas anak dalam belajar IPS tidak begitu terlihat dan cenderung membosankan. Solusi dari permasalahan tersebut yaitu harus dikembangakannya suatu model pembelajaran yang mampu membuat anak aktif dalam belajar dan menciptakan situasi belajar yang berbeda dengan menerapkan model pembalajaran aktif dan menyenangkan. Salah satu model pembelajaran yang dapat digunakan adalah model Kooperatif Teknik mencari pasangan kartu. Dalam proses pelaksanaannya, teknik mencari pasangan kartu ini merupakan teknik mengajar yang membantu dalam mencari jalan pemecahan masalah. Teknik ini melibatkan siswa dalam kegiatan pembelajaran Suprijono (2009:120).

Melalui teknik mencari pasangan kartu siswa menggunakan kartu untuk membantu proses pembelajaran dimana siswa diminta untuk menjodohkan antara kartu yang satu dengan yang lainnya yang masing-masing kartu berisikan soal dan jawabannya. Dengan penerapan teknik mencari pasangan kartu ini terjadi proses pembelajaran aktif, kreatif dan inovatif karena siswa dituntut untuk menemukan sendiri penyelesaian permasalahan berupa soal yang di dapat pada kartu soal atau kartu jawabannya. Setelah siswa berhasil menemukan pasangan kartunya siswa tersebut melakukan diskusi dengan pasangan masing-masing yang dibentuk atau ditemukan berdasarkan kartu yang dipegang oleh masing-masing siswa, disamping itu dengan adanya proses mencari pasangan kartu yang dilakukan oleh siswa membuat susana belajar menyenangkan karena berbeda dengan proses belajar yang mereka lakukan selama ini.

Dengan diterapkannya teknik mencari pasangan kartu ini diharapkan tujuan pembelajaran akan tercapai dan proses pembelajaran yang dialami oleh siswa akan lebih bermakna serta pelajaran IPS 
menjadi pelajaran yang menyenangkan dan tidak membosankan, untuk itu dalam proses pembelajaran IPS harus kreatif dan menyenangkan dengan menggunakan teknik mencari pasangan kartu. Dari latar belakang di atas peneliti tertarik untuk melaksanakan penelitian dengan judul peningkatan hasil belajar ips melalui model kooperatif teknik mencari pasangan kartu soal siswa kelas $v$ sd negeri 2 jatimulyo.

\section{METODOLOGI PENELITIAN}

Bentuk penelitian ini adalah Penelitian Tindakan Kelas (PTK). Kunandar (2011:42) PTK adalah merupakan bagian dari penelitian tindakan, dan penelitian pada umumnya. Penelitian Tindakan Kelas (PTK) berupaya untuk memperbaiki pelaksanaan proses pembelajaran dalam rangka peningkatan kualitas ketuntasan nilai (Aqib dkk, 2011:15).

Populasi target penelitian ini adalah siswa SD N 02 Jatimulyo pada tahun ajaran 2015/2016. Subjek dalam penelitian ini adalah siswa kelas $V$ yang berjumlah 14 orang siswa terdiri 9 siswa Laki laki dan 5 siswa Perempuan. Penelitian dilakukan tanggal 8, 15 dan 22 April 2015 Perbaikan Pembelajaran untuk mata pelajaran IPS tiap siklusnya disusun dengan disesuaikan jadwal pelajaran di sekolah. Yaitu sebagai berikut :

Tabel 3.1

Jadwal Penelitian Tindakan Kelas

\begin{tabular}{|c|c|l|l|}
\hline No & Mata Pelajaran & \multicolumn{1}{|c|}{ Siklus } & \multicolumn{1}{|c|}{ Waktu Pelaksanaan } \\
\hline 1 & IPS & Pra siklus & Rabu, 8 April 2015 \\
\hline 2 & IPS & Silus I & Rabu, 15 April 2015 \\
\hline 3 & IPS & Siklus II & Rabu, 22 April 2016 \\
\hline
\end{tabular}

Pengumpulan data yang dilakukan dalam penelitian ini adalah dengan menggunakan tes dalam bentuk pilhan ganda. menggunakan observasi, dan dokumentasi. Analisis data pada penelitian ini menggunakan rumus statistik tes "T" untuk dua sampel kecil ( $\mathrm{N}$ kurang dari 30 ), sedangkan kedua sampel kecil ini satu sama lain mempunyai hubungan. Adapun rumus yang digunakan yaitu : (Sudijono, 2010).

\section{HASIL DAN PEMBAHASAN}

Di permulaan guru seperti biasa mempersiapkan siswa pada pembelajaran yang nyaman dengan cara berdoa, mengabsen, dan menyuruh siswa untuk mempersiapkan alat tulis. Dilanjutkan dengan apersepsi kemudian menjelaskan materi pembelajaran sehingga perhatian siswa lebih terfokus kepada kegiatan pembelajaran memotivasi siswa dengan mengadakan tanya jawab supaya kegiatan pembelajaran menjadi hidup siswa aktif dan ikut berpartisifasi dalam kegiatan pembelajaran, siswa secara berkelompok mengerjakan soal latihan pada lembar kerja siswa (LKS),

Perhitungan pengkategorian pretestTSR dapat dilihat pada skala di bawah ini:

$5,8+1,32=7,12$ Hasil belajar IPA sebelum diterapkan metode pembelajaran tari bambu di kategorikan tinggi.

Antara 4,48 - 7,12 Hasil belajar IPA sebelum diterapkan metode pembelajaran tari bambu di kategorikan sedang.

$5,8-1,32=4,48$ Hasil belajar IPA sebelum diterapkan metode pembelajaran tari bambu di kategorikan rendah.

Tabel 1. Persentase Hasil Belajar IPA Siswa sebelum Diterapkan Metode Pembelajaran Tari Bambu di SD N Ulak Buntar

\begin{tabular}{|c|l|c|c|}
\hline No & Hasil Belajar IPA & Frekuensi & Persentase \\
\hline 1. & Tinggi (Baik) & 1 & $5 \%$ \\
\hline 2. & Sedang & 15 & $75 \%$ \\
\hline 3. & Rendah & 4 & $20 \%$ \\
\hline & JUMLAH & 20 & $100 \%$ \\
\hline
\end{tabular}


Perhitungan pengkategorian posttest TSR dapat dilihat pada skala di bawah ini:

$7,85+1,11=8,96$ Hasil belajar IPA sebelum diterapkan metode pembelajaran tari bambu di kategorikan tinggi.

Antara 6,74 - 8,96 Hasil belajar IPA sebelum diterapkan media benda tiruan di kategorikan sedang. $7,85-1,11=6,74$ Hasil belajar IPA sebelum diterapkan media benda tiruan di kategorikan rendah.

Tabel 2. Persentase Hasil Belajar IPA Siswa sesudah Diterapkan Metode Pembelajaran Tari Bambu di SD N Ulak Buntar

\begin{tabular}{|c|l|c|c|}
\hline No & Hasil Belajar IPA & Frekuensi & Persentase \\
\hline 1. & Tinggi (Baik) & 6 & $30 \%$ \\
\hline 2. & Sedang & 13 & $65 \%$ \\
\hline 3. & Rendah & 1 & $5 \%$ \\
\hline \multicolumn{2}{|c|}{ JUMLAH } & 20 & $100 \%$ \\
\hline
\end{tabular}

Berdasarkan perhitungan data yang telah dilakukan dari hasil penelitian menunjukkan bahwa penerapan metode pembelajaran tari bambu pada mata pelajaran IPA memiliki peningkatan yang cukup baik, jika dilihat rata-rata dari 5,80 sebelum penerapan metode pembelajaran tari bambu menjadi 7,85 setelah penerapan metode tersebut. Dari presentase yang dapat dilihat dari tabel, siswa yang mendapat hasil yang tinggi juga bertambah dari $5 \%$ menjadi $30 \%$, sebelum penerapan metode tersebut siswa kurang memperhatikan serta siswa tidak menarik penjelasan dari peneliti dengan keluar masuk ruang kelas atau melihat keadaan luar, tetapi dengan penerapan metode tersebut siswa sangat memperhatikan serta siswa berantusias untuk mengetahui apa yang dijelaskan dan siswa juga banyak bertanya, keingintahuannya sangatlah tinggi. Kemudian pada siswa yang mendapatkan hasil yang sedang juga berkurang dari $75 \%$ menjadi $65 \%$, siswa yang perhatiannya kurang pada materi yang diberikan oleh peneliti sebelum penerapan metode, tetapi setelah penerapan tersebut siswa berbeda sekali siswa sudah banyak berubah, yang sebelumnya banyak kegiatan sendiri setelah penerapan tersebut siswa tertarik sehingga mengalami peningkatan. Dan yang mendapatkan hasil yang rendah dari $20 \%$ menjadi $5 \%$, siswa mengalami perubahan dengan penerapan metode tersebut siswa bersemangat untuk menerima materi, antusias siswa sangat berbeda dengan adanya penerapan metode tersebut yaitu metode pembelajaran tari bambu.

Hipotesis dalam penelitian ini adalah ada atau tidak ada perbedaanya hasil belajar siswa dalam mata pelajaran IPA kelas IV SD N Ulak Buntar sebelum dan sesudah diajarkan menggunakan metode pembelajaran tari bambu.Dengan menggunakan uji kesamaan dua rata-rata, uji dua pihak, diperoleh rumusan hipotesis sebagai berikut:

$\mathrm{H}_{\mathrm{a}} \quad$ Ada perbedaan yang signifikan hasil belajar siswa sebelum dan sesudah penerapan metode pembelajaran tari bambu pada mata pelajaran IPA di SD N Ulak Buntar.

$\mathrm{H}_{\mathrm{o}} \quad$ Tidak ada perbedaan yang signifikan hasil belajar siswa sebelum dan sesudah penerapan metode pembelajaran tari bambu pada mata pelajaran IPA di SD N Ulak Buntar.

Uji Statistik tentang berhasil atau tidak penerapan metode pembelajaran tari bambu pada mata pelajaran IPA di SD N Ulak Buntar. Peneliti di sini menggunakan uji statistik dengan rumus product moment dan uji test "t" untuk mengetahui ada tidaknya perbandingan penerapan metode pembelajaran tari bambu pada mata pelajaran IPA di SD N Ulak Buntar terhadap hasil belajar.

Melihat pada tabel " $r$ " product moment didapatkan angka df $=18$ pada taraf signifikan $5 \%$ adalah 0,468 dan pada taraf signifikan $1 \%$ adalah 0,590 , dengan demikian harga korelasi product moment yang telah diperoleh 0,887 lebih besar dari harga korelasi pada harga nilai, baik pada taraf signifikan $5 \%$ maupun $1 \%$, maka ada korelasi positif yang signifikan antara penggunaan metode pembelajaran tari bambu dengan hasil belajar siswa.

$\mathrm{H}_{\mathrm{o}}$ ditolak dan $\mathrm{H}_{\mathrm{a}}$ dapat diterima. Adapun perbandingan angka kedua jenis korelasi tersebut adalah sebagai berikut: 
$0,468<0,887>0,590$

Hal ini menunjukkan bahwa antara penggunaan metode pembelajaran tari bambu terhadap hasil belajar siswa di SD N Ulak Buntar terdapat korelasi yang positif.

Besarnya $t$ yang diperoleh dalam perhitungan $\left(t_{o}=12,05\right)$ dan besarnya $t$ yang tercantum pada tabel $t\left(t_{t . t s .5 \%}=2,09\right.$ dan $\left.t_{t . t s .1 \%}=2,86\right)$ maka dapat diketahui bahwa $t_{0}$ lebih besar daripada $t_{t}$; yaitu $2,09<12,05>2,86$.

Jadi, karena $t_{o}$ lebih besar daripada $t_{t}$ maka hipotesa nihil yang diajukan ditolak, ini berarti bahwa adanya perbedaan yang signifikan hasil belajar siswa SD antara sebelum dan sesudah diterapkan metode pembelajaran tari bambu.

Berdasarkan analisis hasil penelitian dan pembahasan menunjukkan bahwa terdapat perbedaan hasil belajar di kelas setelah melakukan pembelajaran yang menggunakan metode pembelajaran tari bambu. Hal ini disebabkan oleh adanya metode yang membantu siswa dalam memahami materi yang diajarkan oleh guru yang dalam hal ini adalah metode pembelajaran tari bambu. Pembelajaran dengan menggunakan metode pembelajaran tari bambu di kelas suasana belajar yang membuat siswa aktif dan partisipasif, sehingga siswa sangat fokus untuk memperhatikan penjelasan materi yang diberikan tidak melakukan aktivitas yang tidak berguna, siswa antusias dalam proses pembelajaran di kelas serta menyenangkan. Hasil belajar yang diperoleh akan baik disebabkan karena dengan adanya keinginan siswa untuk belajar. Metode pembelajaran juga bisa memberikan rangsangan kepada siswa untuk belajar, menjadikan pembelajaran semakin efektif dan efisien dan dapat mengatasi kebutuhan dan problem siswa dalam belajar.

Selain itu berdasarkan penelitian yang dilakukan Finny Khaeriyah, yang judulnya mirip dengan judul peneliti, tetapi dalam hal itu metode yang diterapkan adalah metode cooperative learning. Hasil penelitiannya membuktikan bahwa metode cooperative learning tersebut dapat meningkatkan hasil belajar siswa dapat dilihat dari siklus I ketuntasan nilai siswa yaitu $40,74 \%$ dan siklus II ketuntasan nilai siswa adalah $81,38 \%$, serta dapat dibuktikan bahwa dapat meningkatkan hasil belajar siswa dalam pembelajaran.

Penelitian eksperimen yang peneliti lakukan menghasilkan hal-hal baru dalam penelitian antara lain:Para siswa sangat antusias dalam mengikuti pembelajaran IPA dengan menggunakan metode tari bambu tersebut dalam pembelajaran.Penerapan metode pembelajaran tai bambu dapat memberikan hasil belajar yang baik jika dibandingkan dengan tidak menggunakan metode tersebut.

\section{PENUTUP}

Berdasarkan hasil penelitian dan pembahasan yang telah disajikan pada bab sebelumnya maka dapat disimpulkan bahwa hasil belajar sebelum penerapan metode pembelajaran tari bambu (pree-test) memiliki rata-rata 5,8. Sedangkan hasil belajar setelah penerapan metode pembelajaran tari bambu (post-test) memiliki rata-rata 7,8. Dengan demikian bahwa metode pembelajaran tari bambu yang telah diterapkan ada perbedaan yang signifikan terhadap hasil belajar siswa pada materi perubahan lingkungan, hal ini dapat dilihat dari hasil uji hipotesis dengan membandingkan besarnya $t$ yang diperoleh dalam perhitungan $\left(t_{o}=12,05\right)$ dan besarnya $t$ yang tercantum pada tabel $t\left(t_{t . t s .5 \%}=\right.$ 2,09 dan $t_{\text {t.ts. } 1 \%}=2,86$ ) maka dapat diketahui bahwa $t_{0}$ lebih besar daripada $t_{t}$; yaitu $2,09<12,05$ $>2,86$.

Sarannya adalah penerapan metode pembelajaran tari bambu ini dalam penyediaan tidak membutuhkan biaya yang cukup besar serta membutuhkan waktu yang cukup, sehingga semua guru dapat menggunakan metode ini, serta guru juga harus terampil dalam mengatur waktu dalam pembelajaran. Disarankan kepada guru terkhusus guru IPA agar dapat menggunakan metode yang membuat siswa aktif dan partisipasi sehingga dapat menghasilkan pembelajaran yang dapat membuat semangat belajar siswa serta tidak membosankan. Kemudian,disarankan kepada sekolah untuk tetap memotivasi guru agar selalu menerapkan metode pembelajaran yang membuat siswa aktif dan semangat dalam pembelajaran. Bagi semua pendidik teruslah berupaya untuk dapat terampil dalam menggunakan metode pada saat melaksanakan belajar mengajar di kelas. Karena dengan menggunakan metode pembelajaran akan membantu siswa cepat memahami suatu materi yang disampaikan oleh guru serta pembelajaran tersebut lebih menarik dan menyenangkan. Segala 
sesuatu yang dapat mengembangkan kecerdasan para siswa hendaklah pendidik mengusahakannya dengan memberikan pembelajaran yang efektif dan efisien serta hadirkan mereka dalam setiap do'a, agar kegiatan belajar mengajar mendapatkan keberkahaan dunia akhirat. Amin

\section{UCAPAN TERIMAKASIH}

Terimakasih kepada Ketua STKIP Nurul Huda OKUT, Ketua LPPM STKIP Nurul Huda OKUT, Anggota Jurnal Jemari STKIP Nurul Huda OKUT, Kepala SD N Ulak Buntar beserta jajarannya, dan Dosen-Dosen STKIP Nurul Huda OKUT.

\section{DAFTAR PUSTAKA}

Arikunto.2010. Manajemen Penelitian, Bandung: Rineka Cipta.

Dalyono, M. 2006. Psikologi Pendidikan: Jakarta: Rineka Cipta.

Djamarah. 2002. Psikologi belajar,Jakarta :Rineksa Cipta.

Elymanizar. 2009 Psikologi Pendidikan, Palembang: Rafah Perss.

Rusman. 2010. Model-Model Pembelajaran. Jakarta: Raja Grafindo Persada.

Riyanto. 2010. Strategi belajar Mengajar. Bandung: Pustaka Setia

Sugiyono.2010. Metode Penelitian Kuantitatif dan Kualitatif dan R dan D. Bandung: Alfabeta.

Khaeriyah, Finny. 2016. Peningkatan Hasil Belajar Ilmu Pengetahuan Sosial melalui Metode Cooperative Learning Teknik Group Investigasi. Program Pascasarjana UNJ, Jakarta. 